\title{
Missed opportunities for the diagnosis of Brucella infection among slaughterhouse workers at the Kumasi Abattoir, Ghana
}

\author{
Esimebia Adjovi Amegashie ${ }^{1,2,3}$, Augustina Angelina Annan*1,4, Anthony Afum-Adjei Awuah ${ }^{1}$, Richard Larbi ${ }^{1}$, Nicholas \\ Addofoh ${ }^{1}$, Patrick Kwame Feglo ${ }^{2}$, Ellis Owusu-Dabo ${ }^{1}$ \\ ${ }^{1}$ Kumasi Centre for Collaborative Research in Tropical Medicine (KCCR), Kumasi, Ghana \\ ${ }^{2}$ Department of Clinical Microbiology, Kwame Nkrumah University of Science and Technology, Kumasi, Ghana \\ ${ }^{3}$ Aniniwah Medical Centre, Emena-Kumasi, Ghana \\ ${ }^{4}$ Department of Theoretical and Applied Biology, Kwame Nkrumah University of Science and Technology, Kumasi, Ghana
}

Received: June 14, 2017

DOI: $10.5430 /$ jer.v3n2p58
Accepted: July 25, 2017

URL: https://doi.org/10.5430/jer.v3n2p58
Online Published: August 22, 2017

\begin{abstract}
Brucellosis is a zoonotic disease in humans with its public health importance. Laboratory diagnostic methods targeting brucellosis are not performed in hospital settings across Ghana. Very little is known about the comparative diagnostic abilities of the various tests available presently. The aim of this study therefore was to evaluate and compare diagnostic performances of Rose Bengal Plate Test (RBPT), Enzyme Linked Immunosorbent Assay (ELISA) and Polymerase Chain Reaction (PCR) employed in diagnosing Brucella infection. Two hundred and twenty Abattoir workers were randomly selected in Kumasi, Ghana. Blood samples were collected, serum extracted and tested for the presence of anti-Brucella antibodies and compared among three different techniques, using ELISA, RBPT and PCR. From the 220 participants tested for antibodies against Brucella spp., 3 (1.4\%), 4 (1.8\%) and 21 (9.6\%) were positive for Rose Bengal Plate test, anti-Brucella ELISA IgM and anti-Brucella ELISA IgG respectively. A total of 98 (44.5\%) participants tested positive by PCR. The sensitivity, specificity, positive predictive value, negative predictive values and Kappa value for Rose Bengal in comparison with PCR were $66.7 \%, 55.8 \%, 2.0 \%, 100 \%$ and 0.013 respectively while that for ELISA IgG in comparison with PCR were $85.7 \%, 71.3 \%, 18.4 \%, 98.5 \%$ and 0.212 respectively. PCR yielded the highest sensitivity and specificity among the three diagnostic methods in this study and should be considered for use at strategic reference laboratories to augment existing routine serological tests for brucella performed in laboratories in Ghana.
\end{abstract}

Key Words: Brucella, Infection, Slaughterhouse workers, Sensitivity and specificity, Prevalence, Risk factors

\section{INTRODUCTION}

Globally, brucellosis still remains a neglected disease in livestock with serious zoonotic implications to humans. ${ }^{[1]}$ There are six identified Brucella species, with three known for causing zoonotic infection. These are B. abortus, B. melitensis and $B$. suis. Transmission of Brucella from infected livestock to humans is caused by direct contact with infected material and through ingestion of infected animal products. ${ }^{[2]}$

About 500,000 new cases of brucellosis are reported every year ${ }^{[1-3]}$ though this figure is underestimated due to lack of appropriate investigative techniques as stated by the World Health Organization suggests. Consequently, brucellosis is a public health disease in livestock and humans in many

*Correspondence: Augustina Angelina Annan; Email: annan@kccr.de; Address: KCCR, KNUST, Kumasi, Ghana. 
African countries. A study carried out in Uganda observed up to $10 \%$ of human participants in three sub-counties in Kiruhura district being positive to the Brucella infection. ${ }^{[4]}$ A recent similar work undertaken in Sudan reported a seroprevalence of $9.5 \%, 15.3 \%, 24.4 \%$ and $26.5 \%$ in veterinarians, meat inspectors, abattoir workers and animal handlers respectively. ${ }^{[5]}$ A study carried out in Libya recorded a seroprevalence of $40 \%$ among high-risk groups. ${ }^{[6]}$

Clinical diagnosis of human brucellosis is hindered by the difficulty in differentiating it from other febrile-like infectious diseases such as malaria that is prevalent in sub-Saharan Africa ${ }^{[7]}$ Laboratory testing therefore, is the only approach to true diagnosis of human brucellosis. ${ }^{[7]}$ This is achieved either through blood culture, serology and/or Polymerase Chain Reaction (PCR). The blood culture method is reported to be successful in only $60 \%$ cases. ${ }^{[2]}$ This is because the slow growing nature of Brucella can take up to 45 days to grow. ${ }^{[2]}$ Moreover, the required biosafety level, ${ }^{[7]}$ which is appropriate to handle Brucella spp, pathogenic organisms, are not usually available in most developing countries.

In the case of serology, the major antigens of Brucella used are the smooth lipopolysaccharide (smooth-S LPS) and internal-cytosolic proteins. ${ }^{[8]}$ Brucella LPS is a strong immunogen but its epitopes cross-reacts with other Gramnegative bacteria especially Yersinia enterocolitica O:9, Vibrio cholerae O:1, Escherichia coli O:157, Salmonella O:30, Francisella tularensis, etc., thereby increasing the rate of false positivity. ${ }^{[9,10]}$

The Enzyme-linked immunosorbent assay (ELISA) measures immunoglobulin $\mathrm{G}$, immunoglobulin $\mathrm{M}$, and immunoglobulin A, which is sensitive and allows for a better interpretation of the clinical situation. ${ }^{[11]}$ ELISA can detect antibody titers for every class of antibody separately, making this method useful for Brucella determination. ${ }^{[11-14]}$ The ELISA diagnostic method has a higher sensitivity in comparison with other serological methods such as Rose Bengal and standard agglutination tests ${ }^{[15]}$ and is an excellent diagnostic method especially for sero-surveys. ${ }^{[11,16]}$

Application of PCR is the quickest method for detection of Brucella infection by amplification of bacterial genome in blood sample, bone marrow, mucus or cerebrospinal fluid (CSF) ${ }^{[17-21]}$ Molecular diagnosis has been known to minimize the risk associated with handling this potentially infectious specimen. ${ }^{[18]}$ The advantages of PCR are numerous and independent of the disease stage, it is more sensitive than blood cultures and more specific than serological tests. ${ }^{[18,22]}$ Studies have also shown that PCR increases the sensitivity, specificity and speed of testing, ${ }^{[23]}$ although some studies have reported only moderate sensitivity of $50 \%{ }^{[24,25]}$
Genus-specific PCR assays are generally adequate for the molecular diagnosis of human brucellosis. ${ }^{[22]}$ The bcsp31 gene, coding for a 31-kDa immunogenic outer membrane protein conserved among all Brucella spp. is the most common molecular target in clinical applications. ${ }^{[12]}$ Such a genus-specific PCR can help to avoid false-negative results in patients infected with unusual species and biovars. ${ }^{[12]}$

Queipo-Ortuno and others found $100 \%$ sensitivity and $98.3 \%$ specificity by using a B4/B5 primer (B4 is (TGG CTC GGT TGC CAA TAT CAA) and B5 (CGC GCT TGC CTT TCA GGT CTG)) and amplifying a 223-bp fragment of the bcsp31 gene compared with $70 \%$ constituents of blood culture. ${ }^{[26]} \mathrm{A}$ study carried out by Sulima and Co confirmed that RBPT detected $4.6 \%$, culture detected $5.9 \%$ while PCR detected $7.4 \%$ Brucella infection among high risk group in India. ${ }^{[27]}$ Also, Khozravi and Co reported sensitivities of cultures and PCR as $26.6 \%$ and $93.3 \%$ respectively in detecting Brucella melintensis among clinically confirmed brucellosis patients. ${ }^{[28]}$ In the meantime, data on comparative analysis of different tests within one sample population are scarse, although the superiority of PCR remains unequivocal.

The aim of this study therefore, was to help identify what proportion of cases could be potentially missed out on routine use of serological methods (Rose Bengal Test and ELISA Method) and to help situate the role of PCR in improving the case detection and control of Brucella in Ghana.

\section{METHODS}

\subsection{Design, setting and sampling}

This was a cross sectional study conducted at the Kumasi Abattoir, a slaughterhouse located in Kaase, a suburb of Kumasi. The Kumasi Abattoir was established in 1997 with grants from the Government of Ghana and the Canadian International Development Agency (CIDA). It commenced operations in 1998. Livestock to be slaughtered at the Kumasi Abattoir are mainly transported from the Brong Ahafo and Northern Regions of Ghana. Some animals are transported from neighboring Burkina Faso, Mali and Niger. There is a cattle market at the abattoir premises. At the cattle market are kraals, which are used to house the animals for sale. A total of 250 cattle and 150 sheep and goats and 100 pigs are slaughtered daily at the abattoir. After slaughter and dressing, the carcasses are distributed to meat shops and cold stores in and around Kumasi (Frimpong et al., 2011). An estimated 340 people work in the abattoir.

We then estimated the sample size of participants for the study assuming a 95\% CI and if 50\% of the workers would have been infected, a default study power of $80 \%$, and an alpha of 5\% and a non-response rate of $15 \%$ and allowing 
an error rate of $10 \%$, then we would require approximately 220 workers for the current study. The study was conducted between May and August 2013.

\subsection{Sample collection and laboratory analysis}

We sought permission from all workers and the authorities at the abattoir before data collection began. We explained to participants the study objectives in the local dialect. After obtaining informed consent from participants, four milliliters of blood was drawn from their upper arm and stored in plain tubes. Blood samples were transported in an ice chest with cooling elements to the laboratories of Kumasi Centre for Collaborative Research in Tropical Medicine (KCCR), for analysis.

We centrifuged blood samples to extract the sera. The sera were stored at $20^{\circ} \mathrm{C}$ and later tested for Brucella spp. using Rose Bengal Test and ELISA diagnostic assays. Each serum was tested for Brucella using the following assays.

\subsubsection{Rose bengal plate test}

For Rose Bengal, the presence of agglutination indicates the presence of anti-Brucella IgG in human sera.

\subsubsection{ELISA method}

ELISA test for anti-Brucella IgM and IgG antibodies were used to analyze the sera. For IgM antibodies, indices indicating values of $<15 \mathrm{U} / \mathrm{ml}$ was considered as negative; $15-20$ $\mathrm{U} / \mathrm{ml}$ as borderline and $>20 \mathrm{U} / \mathrm{ml}$ as positive. While for $\mathrm{IgG}$ antibodies, indices of $<20 \mathrm{U} / \mathrm{ml}$ were considered negative; 20-30 U/ml were borderline and $>30 \mathrm{U} / \mathrm{ml}$ were positive.

\subsubsection{Polymerase Chain Reaction (PCR)}

DNA extraction: DNA was extracted from the serum samples by following the Genotype DNA Isolation Kit protocol (Hain Lifescience GmbH, Nehren, Germany).

Amplification and detection: PCR assay amplified a 223bp sequence gene encoding an immunogenic outer membrane protein of $31 \mathrm{kDa}$ Brucella abortus antigen conserved in all Brucella species making use of Primers B4 (TGG CTC GGT TGC CAA TAT CAA) and B5 (CGC GCT TGC CTT TCA GGT CTG). We performed a master mix scheme of $50 \mu \mathrm{l}$ reaction. The reaction volume contained $10 \mu \mathrm{l}$ DNA template, $5 \mu \mathrm{l} 10 \mathrm{x}$ Buffer, $3.5 \mu \mathrm{l} \mathrm{MgCl}_{2}$ (25 mM), $1.5 \mu \mathrm{l}$ deoxynucleoside triphosphate (dNTP), a $1 \mu$ l of the primer B4 (10 pmol) and $1 \mu \mathrm{l}$ of the primer B5 (8 pmol), $0.5 \mu \mathrm{l}$ of Hotstar Taq polymerase and $27.5 \mu \mathrm{l}$ of RNAse free water. PCR cycling conditions used consisted of an initial 15 min incubation step at $95^{\circ} \mathrm{C}$, followed by 38 cycles of denaturation at $94^{\circ} \mathrm{C}$ for 1 min, annealing at $57^{\circ} \mathrm{C}$ for $1 \mathrm{~min}$, and extension at $72^{\circ} \mathrm{C}$ for $1 \mathrm{~min}$, with a final incubation step at $72^{\circ} \mathrm{C}$ for $10 \mathrm{~min}$.

Following amplification, we visualized the amplified products by fluorescence after electrophoresis using a $2 \%$ agarose gel stained with ethidium bromide $(1 \mu \mathrm{g} / \mathrm{ml})$ under Ultra Violet light. Positive control (Brucella melitensis $16 \mathrm{M}$ ) and negative control (RNAse free water) were added to validate the test.

\subsection{Data analysis}

Data were entered into Epi Info version 3.4.3 and analyzed using STATA version 12.0 (STATACORP, USA). Descriptive statistics of the variables were analysed and presented in the form of tables and graphs and proportions using Microsoft Excel 2007. Using PCR, proportions for the various diagnostic methods were compared for Rose Bengal Test, ELISA $\operatorname{IgM}$ and IgG and are presented as percentages. Positive and Negative predictive values (PPV and NPV) for each test was calculated. The sensitivity, specificity, positive predictive value, and negative predictive value for each of the serological tests in comparison with PCR method were calculated using Stata version 12.0 (STATACORP, USA).

\subsection{Ethical considerations}

The Committee on Human Research Publication and Ethics of the Kwame Nkrumah University of Science and Technology, Kumasi-Ghana approved for the study to be carried out (Ref No. CHRPE/AP/123/13).

\section{RESUlts}

\subsection{Brucella Rose Bengal test, ELISA and PCR results}

A total of 220 participants were recruited for the study of which 218 (99.1\%) were males. Of these, 126 (57.3\%) tested positive by any of the diagnostic methodologies. A total 98 $(44.5 \%)$ tested positive by PCR. Of the positive detections, $3(1.4 \%)$ were by Rose Bengal Plate test, 4 (1.8\%) by antiBrucella ELISA IgM, $21(9.6 \%)$ for anti-Brucella ELISA IgG (see Table 1).

Table 1. Results of ELISA IgM, ELISA IgG, Rose Bengal and PCR Tests

\begin{tabular}{lllll}
\hline \multirow{2}{*}{ Test/Result } & \multirow{2}{*}{ Rose Bengal } & ELISA & IgG & \multirow{2}{*}{ PCR } \\
\cline { 3 - 5 } & & IgM & $21(9.6 \%)$ & $98(44.5 \%)$ \\
\hline Positive (\%) & $3(1.4 \%)$ & $4(1.8 \%)$ & $199(90.4 \%)$ & $122(55.5 \%)$ \\
Negative (\%) & $217(98.6 \%)$ & $216(98.2 \%)$ & & \\
\hline
\end{tabular}


Table 2. Comparison of PCR results with Rose Bengal, ELISA IgM and ELISA IgG results for the diagnosis of Brucella infection

\begin{tabular}{|c|c|c|c|c|c|c|c|}
\hline \multirow{2}{*}{\multicolumn{2}{|c|}{ Test/Result }} & \multicolumn{2}{|c|}{ ROSE BENGAL } & \multicolumn{2}{|c|}{ ELISA IgM } & \multicolumn{2}{|c|}{ ELISA IgG } \\
\hline & & Neg. & Pos. & Neg. & Pos. & Neg. & Pos. \\
\hline \multirow{2}{*}{ PCR } & Neg. & 121 & 1 & 122 & 0 & 119 & 3 \\
\hline & Pos. & 96 & 2 & 94 & 4 & 80 & 18 \\
\hline \multicolumn{2}{|c|}{ TOTAL } & 217 & 3 & 216 & 4 & 199 & 21 \\
\hline
\end{tabular}

Table 3. Positive Correlation between the diagnostic methods used in detecting Brucella infection

\begin{tabular}{llll}
\hline Test Types & No of positives & \multicolumn{1}{c}{ Test Type } & No of Positives \\
\hline Rose Bengal/IgM & 1 & Rose Bengal/IgG/PCR & 1 \\
Rose Bengal/IgG & 3 & Rose Bengal/IgM/PCR & 0 \\
Rose Bengal/PCR & 2 & IgM/IgG/PCR & 3 \\
Rose Bengal/IgM/IgG & 0 & Roser Bengal/IgM/IgG/PCR & 1 \\
IgM/IgG & 3 & IgG/PCR & 19 \\
\hline
\end{tabular}

Two out of the 3 sera that were positive in the Rose Bengal Plate test, were also positive for PCR. All the four sera that were positive in the ELISA IgM were also positive by PCR. When PCR was used as the gold standard for comparison, a total of $85.7 \%$ (19/21) was positive for ELISA IgG were also positive by PCR. Three (3) tested positive for IgM, IgG and PCR while only one person tested positive for all the methods used (see Table 2).

Table 4. Comparison of the Sensitivity, Specificity, Positive and Negative Predictive Values for Rose Bengal, ELISA IgM and IgG with PCR as the gold standard

\begin{tabular}{llll}
\hline & Rose Bengal & ELISA IgM & ELISA IgG \\
\hline Sensitivity & $66.7 \%$ & $100 \%$ & $85.7 \%$ \\
Specificity & $55.8 \%$ & $56.8 \%$ & $59.8 \%$ \\
PPV & $2.0 \%$ & $4.1 \%$ & $18.4 \%$ \\
NPV & $99.2 \%$ & $100 \%$ & $98.5 \%$ \\
Kappa Value & 0.013 & 0.045 & 0.212 \\
\hline
\end{tabular}

\subsection{Rose Bengal and ELISA tests compared with PCR}

When PCR is used as the gold standard with comparison with Rose Bengal test, Rose Bengal test gave a sensitivity of $66.7 \%(2 / 3 * 100)$ and a specificity of $55.8 \%(121 / 217 * 100)$. Thus, the positive predictive value (PPV) and negative predictive value (NPV) of Rose Bengal is 2.0\% (2/98*100) and $99.2 \%(121 / 122 * 100)$ respectively (see Table 4$)$.

When PCR was compared with ELISA IgM, ELISA IgM gave a sensitivity of $100 \%(4 / 4 * 100)$ and a specificity of $56.8 \%\left(122 / 216^{*} 100\right)$. Thus, the PPV and NPV of ELISA $\operatorname{IgM}$ is $4.1 \%(4 / 98 * 100)$ and $100 \%(122 / 122 * 100)$ respectively (see Table 4 ).

Also when PCR was compared with ELISA IgG, ELISA IgG Published by Sciedu Press gave a sensitivity of $85 \%\left(18 / 21^{*} 100\right)$ and a specificity of $59.8 \%(119 / 199 * 100)$. Thus, the PPV and NPV of ELISA IgG is $18.4 \%(18 / 98 * 100)$ and $98.5 \%(199 / 202 * 100)$ respectively (see Table 4).

Table 5. Distribution of ages to positive cases among the various methods analyzed

\begin{tabular}{llllll}
\hline Ages & Total & $\begin{array}{l}\text { Rose Bengal } \\
\text { (POS) }\end{array}$ & $\begin{array}{l}\text { IgM } \\
\text { (POS) }\end{array}$ & $\begin{array}{l}\text { IgG } \\
\text { (POS) }\end{array}$ & $\begin{array}{l}\text { PCR } \\
\text { (POS) }\end{array}$ \\
\hline >30 yrs & 52 & 0 & 0 & 1 & 25 \\
30-39 yrs & 84 & 1 & 4 & 10 & 34 \\
40-49 yrs & 57 & 1 & 0 & 7 & 25 \\
50+ yrs & 27 & 1 & 0 & 3 & 14 \\
\hline
\end{tabular}

Ages 30-39 showed the highest rate of positivity for PCR (34), ELISA IgM (4) and IgG (10) whiles ages 50 and above showed the lowest rate of positivity for PCR (14), ELISA $\operatorname{IgM}(0)$ and $\operatorname{IgG}(3)$ (see Table 5).

\section{Discussion}

Brucellosis is an occupational disease placing abattoir workers, veterinarians, butchers, cattle rearers, farmers etc. at higher risk of acquiring this infection. ${ }^{[2]}$ Our study indicates that of the three tests, PCR had the highest positivity of $44.5 \%$ and the Rose Bengal test the lowest for detecting Brucella infection with a positivity of $1.4 \%$.

A study carried out by Ruiz-Mesa and Co reported a low performance by Rose Bengal test for those who had been exposed repeatedly to Brucella infection as compared to those who have no exposure to or history of brucellosis. A similar study in Ghana, ${ }^{[30]}$ reported a $0 \%$ prevalence of human Brucella infection in selected risk groups in the Akwapim South 
district using the Rose Bengal test. However, they did not compare their results with any of the other diagnostic methods. This may be the result of poor sensitivity of the RBT. Therefore the use of Rose Bengal in diagnosing Brucella infection among high-risk group should be carefully considered and perhaps supplemented at strategic laboratories with PCR.

The ELISA method, which was used to detect anti-Brucella $\operatorname{IgM}$ (recent infection) while anti-Brucella IgG (past infection) gave prevalence of $1.8 \%$ and $9.6 \%$ respectively. In Nigeria, ${ }^{[13]} 9.8 \%$ prevalence was reported among abattoir workers making use of the ELISA method. An Iranian study among slaughterhouse workers who also used the ELISA IgM method, ${ }^{[29]}$ recorded a prevalence of $6.9 \%$ which was higher than our estimated $1.8 \%$.

The indication of PCR's performance in this study contrasts with findings from Hajia and Rahbar where higher prevalence of $48.9 \%$ compared to $84 \%$ for ELISA in $\operatorname{Iran}^{[31]}$ was reported. Their study however was cohort; targeting human patients suspected of having Brucellosis and has been referred to a hospital in Iran. Amirzargar and others also reported a prevalence of $50 \%$ when they employed PCR in assessing Brucella infection among hospitalized patients in Iran. ${ }^{[31]}$

Germechu and others, however reported a lower prevalence of $7 \%$ for PCR in a study they carried out in India. ${ }^{[32]}$ Elfaki and others detected Brucella infection of $40 \%$ and $70 \%$ by culture and PCR respectively. They concluded that detection of antibody against Brucella spp. is not always related to disease condition and that it has to be followed up by either culture or PCR. ${ }^{[33]} 95$ (43.1\%), 94 (42.7\%) and 77 (34.9\%) of participants were missed for Rose Bengal and ELISA IgM and $\operatorname{IgG}$, respectively when compared with the PCR method. Brucella spp is antigen encoded which enters a host cell and induces an immune response leading to a rise in antibodies production therefore being easily identified by serological testing while PCR detects the presence of the DNA in a host cell. This is so for serological methods because most of the subject may be in their "window period" where the foreign body needs to stimulate the production of antibodies, which take some time to occur. This has made evaluation more difficult leading to a false negative results. ${ }^{[9]}$

From this study, there were missed diagnosis with Rose Bengal, ELISA IgM and IgG. These missed diagnosis if not confirmed by a highly sensitive test like PCR would lead to the patient being treated for other febrile like diseases like malaria, thereby worsen the prognosis of the infection. ${ }^{[2]}$ Also, patients with active disease cannot be easily differentiated from people with past brucellosis by serologic test results. On the one hand, the sole detection of anti-Brucella antibodies does not provide evidence for the presence of the pathogen.$^{[2]}$ Missed cases can end up in complications of brucellosis such as Epididymo-ochitis, ${ }^{[34]}$ neurobrucellosis ${ }^{[35]}$ and abortion in pregnant women. ${ }^{[36]}$

Nineteen (19) tested positive for both IgG and PCR, giving us a higher number when using these two methods in diagnosing Brucella infection are compared to other combined method. This may be suggestive of the cases where PCR is not available, the ELISA IgG method can be used. This finding was also supported by Osoba et al., who confirmed from their study that ELISA IgG was an effective method in diagnosing Brucella infection. ${ }^{[37]}$

From this study, a sensitivity of $66.7 \%$, specificity of $55.8 \%$, Positive Predictive Value of $2.0 \%$ and Negative Predictive value of $99.2 \%$ for Rose Bengal in comparison with PCR tests and the sensitivity of $85.7 \%$, specificity of $59.8 \%$, Positive Predictive value of $18.4 \%$ and a Negative Predictive value of $98.5 \%$ for ELISA IgG in comparison with PCR was reported. The higher Negative Predictive values for Rose Bengal test and ELISA IgG indicate that these tests were highly specific.

Kappa values of 0.013 and 0.045 for Rose Bengal Plate Test and ELISA IgM respectively indicate that these methods are poor in diagnosing Brucella infection, although these highrisk groups have repeated chances of exposure. Kappa value of 0.212 indicates that ELISA IgG is fairly good in diagnosing Brucella infection, therefore, a better alternative in cases where PCR is not available. These findings are consistent with reports from other studies making PCR a gold standard in diagnosing Brucella infection. ${ }^{[18,38]}$ Queipo-Ortuno and others also made use of the same primers, B4/B5 primer, amplifying a 223-bp fragment of the bcsp31 gene and found $100 \%$ sensitivity and $98.3 \%$ specificity as compared with $70 \%$ constituents of blood culture. ${ }^{[29]}$ PCR has a higher sensitivity and specificity than serological tests and is able to detect as little as 30 femtograms (fg) of Brucella DNA, therefore a useful tool in confirming Brucella infection. ${ }^{[39-43]}$

The higher sero-positivity among the age group 30-39 years could be due to the fact that the majority of the active workforce at the abattoir falls within this age group. Other studies reported an average age of 34.4 years in Kuwait, ${ }^{[44]} 33.8$ years in Saudi Arabia ${ }^{[45]}$ and 31.6 years in Djibouti. ${ }^{[46]}$ The higher sero-positivity is observed in this age group due to them having been exposed longer to risk factors related to their occupation with majority working in close contact with animal fluids as compared to the older ages.

Unfortunately, WHO does not recommend the use PCR rou- 
tinely due to associated cost implications, especially in resource poor countries. It must be noted that even though PCR has a disadvantage of being expensive and requires highly skilled personnel to deliver the service as compared with that of serological methods, some level of emphasis should be placed on it at least at referral laboratories to help improve case detection. Also one must compare the cost of PCR with the cost of having Brucella detection and the consequences of not knowing one's status.

\section{Conclusion}

This study has shown that a substantial number of Brucella cases are missed when Rose Bengal and ELISA is used in detecting Brucella infection among the study population while molecular techniques show superiority in diagnosis and overwhelmingly improved case detection. A total 95 (43.1\%), 94 $(42.7 \%)$ and 77 (34.9\%) of participants were missed when Rose Bengal and ELISA IgM and IgG diagnostic assays were used, respectively. Our study recommends the establishment of a local quality control system at the institutional level to provide reliability of serological methods and the establishment of a PCR "buffer system" at designated places to help supplement serological methods.

\section{Authors' CONTRIBUTIONS}

E.A.A. contributed to the design of work, acquisition of data and samples, laboratory analysis and interpretation of data and drafting the article. A.A.A.A. contributed to experimental design, laboratory analysis and manuscript preparation. R.L. contributed to experimental design and laboratory analysis. N.A. contributed to statistical design, analysis and interpretation of data and preparation of manuscript. E.O.D, A.A and P.F. contributed to conception and design of work, analysis and interpretation of data, contributed and supervised manuscript preparation.

\section{ACKNOWLEDGEMENTS}

This research work was performed with funding from The African Programme for Advanced Research Epidemiology Training (2012/APARET/06). The study team is grateful to the staff and management of Kumasi Abattoir for the permission to carry out this work in their facility.

\section{CONFlicts of InTEREST Disclosure}

The authors declare that they have no competing interests.

\section{REFERENCES}

[1] Pappas G, Papadimitriou P, Akritidis N, et al. The new global map of human brucellosis. The Lancet Infectious Diseases. 2006; 6(2): 91-9. https://doi.org/10.1016/S1473-3099(06) 70382-6

[2] Corbel MJ. Brucellosis in humans and animals: World Health Organization; 2006.

[3] Ariza J, Bosilkovski M, Cascio A, et al. Perspectives for the treatment of brucellosis in the 21st century: the Ioannina recommendations. PLOS Medicine. 2007; 4(12): e317. PMid:18162038 https: //doi.org/10.1371/journal.pmed.0040317

[4] Kasiita H, Mugisha S, Rweog I. Human serology survey in three subcounties adjacent to Lake Mburo National Park in Kiruhura District, Uganda. Makerere University-International Development Research Centre, Canada. Project Report. 2012.

[5] Zein AM, Sabahelkhier MK. Prevalence of Brucellosis among High Risk Groups in Northern State, Sudan. Nova Journal of Medical and Biological Sciences. 2016; 4(1).

[6] Ahmed MO, Elmeshri SE, Abuzweda AR. Seroprevalence of brucellosis in animals and human populations in the western mountains region in Libya, December 2006-January 2008. Euro Surveill. 2010; 15(30): 19625-8. PMid:20684813

[7] Al Dahouk S, Tomaso H, Nöckler K, et al. Laboratory-based diagnosis of brucellosis-a review of the literature. Part II: serological tests for brucellosis. Clinical Laboratory. 2002; 49(11-12): 577-89.

[8] Nielsen K, Smith P, Widdison J, et al. Serologicalrelationshipbetween cattle exposed to Brucella abortus, Yersinia enterocolitica O: 9 and Escherichia coli O157: H7. Veterinary Microbiologg. 2004; 100(1): 25-30.

[9] Nielsen K, Lin M, Gall D, et al. Fluorescence Polarization Immunoassay: Detection of Antibody to Brucella abortus. Methods. 2000; 22(1): 71-6. PMid:11020320 https://doi.org/10.1006/meth .2000 .1038

[10] Gall D, Nielsen K. Serological diagnosis of bovine brucellosis: a review of test performance and cost comparison. Revue scientifique et technique (International Office of Epizootics). 2004; 23(3): 989. https://doi.org/10.20506/rst.23.3.1545

[11] Araj GF. Update on laboratory diagnosis of human brucellosis. International Journal of Antimicrobial Agents. 2010; 36: S12S7. PMid:20692128 https://doi.org/10.1016/j.ijantimi cag. 2010.06.014

[12] Baddour MM, Alkhalifa DH. Evaluation of three polymerase chain reaction techniques for detection of Brucella DNA in peripheral human blood. Canadian Journal of Microbiology. 2008; 54(5): 352-7. PMid:18449219 https://doi.org/10.1139/W08-017

[13] Aworh MK, Okolocha E, Kwaga J, et al. Human brucellosis: seroprevalence and associated exposure factors among abattoir workers in Abuja, Nigeria-2011. Pan African Medical Journal. 2013; 16(103). https://doi.org/10.11604/pamj.2013.16.103.2143

[14] Pappas G, Akritidis N, Tsianos E. Effective treatments in the management of brucellosis. Expert Opinion on Pharmacotherapy. 2005; 6(2): 201-9. PMid:15757417 https://doi.org/10.1517/1465 6566.6 .2 .201

[15] Giambartolomei GH, Delpino MV, Cahanovich ME, et al. Diminished production of $\mathrm{T}$ helper 1 cytokines correlates with $\mathrm{T}$ cell unresponsiveness to Brucella cytoplasmic proteins in chronic human brucellosis. Journal of Infectious Diseases. 2002; 186(2): 252-9. PMid:12134263 https://doi.org/10.1086/341449

Published by Sciedu Press 
[16] Smits HL, Kadri SM. Brucellosis in India: a deceptive infectious disease. Indian Journal of Medical Research. 2005; 122(5): 375 PMid:16456249

[17] Queipo-Ortuño MI, Colmenero JD, Baeza G, et al. Comparison between LightCycler Real-Time Polymerase Chain Reaction (PCR) assay with serum and PCR-enzyme-linked immunosorbent assay with whole blood samples for the diagnosis of human brucellosis. Clinical Infectious Diseases. 2005; 40(2): 260-4. PMid:15655745 https://doi.org/10.1086/426818

[18] Navarro E, Casao MA, Solera J. Diagnosis of human brucellosis using PCR. Expert Review of Molecular Diagnostics. 2004; 4(1): 115-23. PMid:14711354 https://doi .org/10.1586/14737159 .4 .1 .115

[19] Zerva L, Bourantas K, Mitka S, et al. Serum is the preferred clinical specimen for diagnosis of human brucellosis by PCR. Journal of clinical microbiology. 2001; 39(4): 1661-4. PMid:11283112 https://doi.org/10.1128/JCM.39.4.1661-1664.2001

[20] Al-Nakkas A, Mustafa AS, Wright SG. Large-scale evaluation of a single-tube nested PCR for the laboratory diagnosis of human brucellosis in Kuwait. Journal of Medical Microbiology. 2005; 54(8): 727-30. PMid:16014425 https ://doi .org/10.1099/jmm.0.45 772-0

[21] Nimri LF. Diagnosis of recent and relapsed cases of human brucellosis by PCR assay. BMC infectious diseases. 2003; 3(1): 5 PMid:12718759 https ://doi .org/10.1186/1471-2334-3-5

[22] Al Dahouk S, Neubauer H, Tomaso H. Brucella. In Molecular detection of human bacterial pathogens (D. Liu, ed.). Taylor \& Francis, CRC Press, Boca Raton, Florida, 2011; 629-646. https : //doi.org/10.1201/b10848-61

[23] Al-Attas RA, Al-Khalifa M, Al-Qurashi AR, et al. Evaluation of PCR, culture and serology for the diagnosis of acute human brucellosis. Annals of Saudi Medicine. 2000; 20(3/4): 224-8. PMid:17322662 https ://doi.org/10.5144/0256-4947.2000.224

[24] Amirzargar A, Hassibi M, Maleknejad P, et al. Comparison of diagnostic methods in hospitalized patients with brucellosis in Iran Infectious Diseases in Clinical Practice. 2009; 17(4): 239-42. https : //doi.org/10.1097/IPC.0b013e31818718e8

[25] Probert WS, Schrader KN, Khuong NY, et al. Real-time multiplex PCR assay for detection of Brucella spp., B. abortus, and B. melitensis. Journal of Clinical Microbiology. 2004; 42(3): 1290 3. PMid: 15004098 https://doi.org/10.1128/JCM.42.3.129 $0-1293.2004$

[26] Queipo-Ortuno M, Tena F, Colmenero J, et al. Comparison of seven commercial DNA extraction kits for the recovery of Brucella DNA from spiked human serum samples using real-time PCR. European Journal of Clinical Microbiology \& Infectious Diseases. 2008; 27(2): 109-14. PMid:17973130 https : //doi .org/10.1007/s10096-0 07-0409-y

[27] Maher S, Gunaseelan L, Venkataraman KS, et al. Laboratory confirmation of human brucellosis in high risk groups. Tamilnadu J. Veterinary \& Animal Sciences. 2012; 8(6): 345-350.

[28] Khozravi AD, Abassi E, Alavi SM. Isolation of Brucella melitensis andBrucella abortus from brucellosis patients by conventional culture method and polymerase chain reaction technique. Pak J Med Sci. 2006; 22(4): 396-400.

[29] Nikokar I, Hosseinpour M, Asmar M. Seroprevalence of Brucellosis among high risk individuals in Guilan, Iran. Journal of Research in Medical Sciences: the Official Journal of Isfahan University of Medical Sciences. 2011; 16(10): 1366.

[30] Kubuafor D, Awumbila B, Akanmori B. Seroprevalence of brucellosis in cattle and humans in the Akwapim-South district of
Ghana: public health implications. Acta Tropica. 2000; 76(1): 45-8. https://doi .org/10.1016/S0001-706X (00)00088-7

[31] Hajia M, Rahbar M. Isolation of Brucella from blood culture of hospitalized brucellosis patients. Archives of Clinical Infectious Diseases. 2006; 1(2).

[32] Gemechu MY, Gill JPS, Arora AK, et al. Polymerase chain reaction (PCR) assay for rapid diagnosis and its role in prevention of human brucellosis in Punjab, India. International Journal of Preventive Medicine. 2011; 2(3): 170.

[33] Elfaki MG, Uz-Zaman T, Al-Hokail AA, et al. Detection of Brucella DNA in sera from patients with brucellosis by polymerase chain reaction. Diagnostic Microbiology and Infectious Disease. 2005; 53(1): 1-7. PMid:16054326 https ://doi.org/10.1016/j.diag microbio.2005.03.011

[34] Akinci E, Bodur H, Cevik MA, et al. A complication of brucellosis: epididymoorchitis. Int J Infect Dis. 2006; 10: 171-7. PMid:16360332 https://doi.org/10.1016/j.ijid.2005.02.006

[35] Yetkin MA, Bulut C, Erdinc FS, et al. Evaluation of the clinical presentations in neurobrucellosis. Int J Infect Dis. 2006; 10: 446-52. PMid:16914346 https ://doi.org/10.1016/j.ijid.2006.05 .007

[36] Kurdoglu M, Adali E, Kurdoglu Z, et al. Brucellosis in pregnancy: a 6-year clinical analysis. Arch Gynecol Obstet. 2010; 281: 201-6. PMid:19434417 https : //doi .org/10.1007/s00404-009-110 6-0

[37] Osoba OA, Balkhy H, Memish Z, et al. Diagnostic value of Brucella ELISA IgG and IgM in bacteremic and non-bacteremic patients with brucellosis. J. Chemother. 2001; 13(Suppl.1): 54-59. PMid:11434531 https://doi.org/10.1080/1120009X .2001.11782330

[38] Queipo-Ortuño MI, Morata P, Ocon P, et al. Rapid diagnosis of human brucellosis by peripheral-blood PCR assay. Journal of Clinical Microbiology. 1997; 35(11): 2927-32.36. https://doi .org/10.1 $136 / v r .147 .22 .634$

[39] Guarino A, Serpe L, Fusco G, et al. Detection of Brucella species in buffalo whole blood by gene-specific PCR. Veterinary Record. 2000; 147(22): 634-6. https://doi.org/10.1136/vr.147.22.634

[40] Gupta V, Kumari R, Vohra J, et al. Comparative evaluation of recombinant BP26 protein for serological diagnosis of Brucella melitensis infection in goats. Small Ruminant Research. 2010; 93(2): 119-25. https://doi.org/10.1016/j.smallrumres.2010.05.009

[41] Amin AS, Hamdy ME, Ibrahim AK. Detection of Brucella melitensis in semen using the polymerase chain reaction assay. Veterinary Microbiology. 2001; 83(1): 37-44. https ://doi.org/10.1016/ S0378-1135(01) 00401-1

[42] KANANI AN. Serological, cultural and molecular detection of Brucella infection in breeding bulls: ANAND AGRICULTURAL UNIVERSITY; 2007.

[43] PATEL TJ. Master of Veterinary Science: ANAND AGRICULTURAL UNIVERSITY; 2005.

[44] Karimi A, Alborzi A, Rasooli M, et al. Prevalence of antibody to Brucella species in butchers, slaughterers and others. East Mediterr Health J. 2003; 9: 178-84. PMid:15562749

[45] el-Razik KA, Desouky HM, Ahmed WM. Investigations on brucellosis in Egyptian Baladi Does with emphasis on evaluation of diagnostic techniques. Pak J Biol Sci. 2007; 10: 342-8. PMid:19070039 https ://doi.org/10.3923/pjbs. 2007.342.348

[46] Lobna MAS, Khoudair MR, Osman SA. Sero Diagnosis of Brucellosis by Using Simple and Rapid Field Tests with Emphasis on Some Possible Risk Factors in Humans Global Veterinaria. 2014; 12 (3): 320-325. 